\title{
FAKTOR-FAKTOR YANG MEMPENGARUHI PENDAPATAN PENGRAJIN INDUSTRI BATU TATAKAN MUTIARA GUNUNG DESA LEMPANG KECAMATAN TANETE RIAJA KABUPATEN BARRU
}

\author{
Siti Aisyha, Rini Asrawati Aras \\ Universitas Islam Negeri Alauddin Makassar \\ Jl. H.M. Yasin Limpo No.62. Romangpolong-Gowa \\ siti.aisyah@yahoo.co.id
}

\begin{abstract}
This study aims to determine the effect of business capital, selling prices, and marketing on the income of the artisans. The sample used in this study is the villagers of Lempang who works as a placemant craftsman. Ttotal sample of 96 craftsman using simple random sampling technique using the slovin formula. The data analysis method used is multiple linear regression with the application of eviews 9. The results showed that the business capital and marketing have a positive effect on the income of the stone craftsman, while the selling price has a negative effect on the income of the Tanete Riaja, Barru.
\end{abstract}

Abstrak: Penelitian ini bertujuan untuk mengetahui pengaruh modal usaha, harga jual, dan pemasaran terhadap pendapatan pengrajin batu tatakan. Sampel yang digunakan dalam penelitian ini yaitu masyarakat desa lempang yang bermata pencaharian sebagai pengrajin batu tatakan. Total sampel berjumlah 96 pengrajin dengan menggunakan teknik simple random sampling dengan menggunakan rumus slovin. Metode analisis data yang digunakan yaituregresi linear berganda dengan aplikasi eviews 9. Hasil penelitian menunjukkan bahwa modal usaha dan pemasaran berpengaruh positif terhadap pendapatan pengrajin batu tatakan, sedangkan harga jual berpengaruh negative terhadap pendapatan pengrajin batu tatakan di Desa Lempang Kecamatan Tanete Riaja Kabupaten Barru.

Kata Kunci: Pendapatan, Modal Usaha, Harga Jual, Pemasaran, Industri Rumah Tangga

\section{PENDAHULUAN}

Pembangunan ekonomi merupakan hal yang mutlak yang harus dilaksanakan jika suatu bangsa ingin meningkatkan taraf hidup dan kesejahteraan rakyatnya. Pembangunan ekonomi tersebut harus dapat diusahakan dengan kemampuan dan kapasitas yang ada, baik dengan kemampuan bangsa itu sendiri, maupun dengan bantuan negara-negara lain. Dengan kata lain, pembangunan itu sendiri merupakan suatu usaha yang sadar dan terarah dari suatu bangsa untuk meningkatkan kesejahteraan rakyatnya melalui pemanfaatan segala sumber daya yang ada, baik dari dalam maupun dari luar negeri. Pembangunan dibidang ekonomidilaksanakan untuk mewujudkan pemerataan hasil-hasil pembangunan.Salah satu sektor dibidang ekonomi tersebut adalah sektor industri. 
Sektor industri diyakini sebagai sektor yang dapat memimpin sektor-sektor lain dalam sebuah perekonomian menuju kemajuan. Produk-produk industrial selalu memilih "dasar tukar" (term of trade) yang tinggi atau menguntungkan serta menciptakan nilai tambah yang lebih besar dibandingkan produk-produk disektor lain. Hal ini disebabkan karena sektor industri memiliki variasi produk yang sangat beragam dan mampu memberikan manfaat marginal yang tinggi bagi pemakainya (Dumairy, 2006).

Pembangunan pada sektor industri khususnya industri rumah tangga diarahkan agar mampu berkembang secara mandiri dan meningkatkan pendapatan masyarakat.Kenyataan menunjukkan kepada kita bahwa peranan industri rumah tangga mempunyai andil yang sangat tidak kecil dalam perekonomian di masyarakat, baik di negara maju maupun negara berkembang. Besar kecilnya sumbangan sektor industri rumah tangga dalam pembangunan perekonomian masyarakat antara negara yang satu dengan negara yang lain sering berbeda-beda, sesuai dengan kualitas industri yang dimiliki oleh masyarakat yang bersangkutan.

Suatu industri rumah tangga apabila dalam pengolahannya ditangani secara profesional dan menghasilkan produk yang kreatif dan inovatif akan membantu industri tersebut berkembang lebih besar dan dapat bersaing dengan industri sejenis lainnya, sehingga tujuan industri rumah tangga dapat tercapai seperti hasil industri batu tatakan yang ada di Kecamatan Lempang Kabupaten Barru sudah berkembang sejak lama.

Dalam menjalankan usaha yang telah dilakukan oleh masing-masing pengrajin dan kemampuan yang dimiliki, secara langsung akan mempengaruhi pendapatan yang diterima oleh masing-masing pengrajin. Pendapatan tersebut tentunya dipengaruhi oleh beberapa faktor termasuk penggunaan faktor produksi.Beberapa faktor produksi adalah jumlah stok modal, jumlah tenaga kerja yang digunakan, kekayaan alam dan tingkat teknologi yang digunakan (Sukirno, 1999).

Melihat potensinya, usaha kerajinan batu tatakan sangat menjanjikan dan banyak diminati oleh konsumen, karena produk kerajinan batu tatakan sangat beragam dengan berbagai fungsi dari produk-produk hasil kerajinan tersebut.

Berdasarkan proses pengolahan kerajinan batu tatakan ini, mulai dari pengolahan batu gunung hingga menjadi produk yang siap dipasarkan, memakan waktu yang cukup lama dan membutuhkan alat khusus. Hal ini yang sering membuat pengrajin kewalahan dalam memenuhi permintaan konsumen karena modal usaha kerajinan batu tatakan yang masih kurang, sehingga besar kecilnya perkembangan usaha kerajinan batu tatakan salah satunya dipengaruhi oleh modal usaha, dimana semakin besar modal usaha maka semakin banyak produksi yang mampu dikerjakan guna memenuhi permintaan konsumen.

Beberapa produk kerajinan batu tatakan di antaranya adalah kerajinan yang berupa alat rumah tangga seperti cobekan/ulekan dan lesung, batu nisan, penyangga rumah dan cipping (kerikil).

Pendapatan usaha kerajinan batu tatakan sangat tergantung pada harga jual produk dan biaya yang dikeluarkan untuk produksi. Semakin tinggi harga jual produksi dan semakin rendah biaya, maka semakin tinggi pendapatan para pengrajin batu tatakan. 
Desa Lempang juga tidak luput dari permasalahan yang dihadapi oleh pengrajin di antaranya : Pertama, masyarakat yang menjadi pengrajin batu tatakan memiliki pendapatan yang berbeda-beda antar pengrajin. Kedua, sulitnya pengembangan usaha kerajinan batu tatakan karena terbatasnya modal. Ketiga, industri batu tatakan dijalankan secara individu dan persaingan dalam penetapan harga produk antar pengrajin sehingga menimbulkan persaingan yang tidak sehat dan berpotensi merugikan pihak lain. Keempat, masalah dalam promosi dan pemasaran hasil dari produksi kerajinan batu tatakan.

Berdasarkan uraian di atas, peneliti mengambil tema mengenai faktor-faktor yang mempengaruhi pendapatan pengrajin industri batu tatakan mutiara gunung Desa Lempang Kecamatan Tanete Riaja Kabupaten Barru. Tujuan penelitian ini untuk mengetahui pengaruh modal usaha, harga jual, dan pemasaran terhadap pendapatan pengrajin batu tatakan mutiara gunung Desa Lempang Kecamatan Tanete Riaja Kabupaten Barru.

\section{TINJAUAN TEORETIS}

\section{Industri Rumah Tangga}

Menurut Undang-undang No. 5 tahun 1984 tentang perindustrian, Industri adalah kegiatan ekonomi yang mengolah bahan mentah, bahan baku, barang setengah jadi dan atau barang jadi menjadi barang-barang dengan nilai yang lebih tinggi untuk penggunaannya, termasuk kegiatan rancang bangunan dan perekayasaan industri.Industripada hakekatnya berarti perusahaan yang menjalankan operasi dalam bidang kegiatan ekonomi yang tergolong kedalam sektor sekunder. Kegiatan seperti itu antara lain ialah pabrik tekstil, pabrik perakit atau pembuat mobil dan pabrik minuman ringan (Sukirno, 2006).

Menurut Mudrajad Kuncoro, industri kecil dan rumah tangga (IKRT) memiliki peranan yang cukup besar dalam sektor manufaktur dilihat dari sisi jumlah unit usaha dan daya serapan terhadap tenaga kerja, namun lemah dalam menyumbang nilai tambah. Sedangkan menurut Soerjono Soekanto, industri rumah tangga merupakan penerapan cara-cara yang kompleks dan canggih terhadap produksi itu, yang secara implisit berarti penggunaan mesin-mesin, dipergunakan untuk meningkatkan kuantitas dan kualitas produksi.

\section{Pendapatan}

Secara teoritis, tingkat pendapatan masyarakat dalam kesatuan wilayah perekonomian pasti tidaklah sama dengan jumlahnya hal mana disebabkan oleh adannya perbedaan keahlian dan pendidikan, jenis pekerjaan, tingkat upah dan lain sebagainya (Manurung, 2016).

Sukirno mengatakan bahwa pada dasarnya pendapatan merupakan balas jasa yang diterima oleh pemilik faktor produksi atas pengorbanannya dalam proses produksi. Masing-masing faktor produksi seperti tanah akan memperoleh balas jasa dalam bentuk sewa tanah, tenaga kerja akan memperoleh balas jasa berupah upah/gaji, modal akan memperoleh balas jasa dalam bentuk bunga modal, serta keahlian termasuk para enterpreneur akan memperoleh balas jasa dalam bentuk laba (Antari, 2008). 
Dari uraian di atas dapat disimpulkan bahwa pendapatan pengrajin batu tatakan adalah hasil atau nilai yang diperoleh pengrajin atau pemilik usaha rumah tangga di Desa Lempang berdasarkan jumlah penjualan dikurangi dengan jumlah pengeluaran yang digunakan dalam kegiatan memproduksi batu tatakan tersebut dalam satu bulan. Oleh karena itu, perkembangan pendapatan yang akan diteliti ditinjau dari faktor-faktor yang mempengaruhi pendapatan pengrajin atau pemilik usaha rumah tangga di Desa Lempang Kecamatan Tanete Riaja Kabupaten Barru.

\section{Modal}

Pada usaha industri penggunaan modal khususnya pada penggunaan sarana produksi erat sekali hubungannya dengan keadaan dilapangan, karena semakin besar produksi yang dikerjakan maka semakin besar pula kebutuhan modal dan tenaga kerja yang harus dipakai untuk dapat meningkatkan pendapatan dari hasil usaha industri yang dilakukan.

Menurut Hendro, modal yang paling penting adalah pengalaman (Hendro, 2011). Sedangkan menurut Muhammad Sharif Chaudry modal adalah kekayaan yang didapatkan manusia melalui tenaganya sendiri dan kemudian menggunakannya untuk menghasilkan kekayaan lebih lanjut (Wijandi, 2004).

Konsep modal yang dijelaskan oleh Wijandi (2004) adalah Modal dalam suatu usaha adalah seperti bahan bakar atau energi penggerak awal sebuah motor. Makin besar motor yang harus digerakkan makin besar pula energi yang ada, akan makin besar pula daya yang dapat dihasilkan. Demikian juga pada modal, makin besar modal yang ada, maka besar pula kemungkinan ukuran usaha yang dijalankan. Usaha kecil cukup dengan modal kecil dan sebaliknya untuk usaha yang besar diperlukan modal yang besar pula. Umumnya istilah modal selalu diasosiasikan atau dikaitkan dengan uang sehingga tidak ada uang berarti tidak ada modal.

Dari pendapat diatas dapat disimpulakan bahwa modal usaha adalah harga yang dimiliki untuk digunakan dalam menjalankan kegiatan usaha dengan tujuan memperoleh laba yang optimal. Sehingga diharapkan bisa meningkatkan pendapatan pengrajin batu tatakan di Desa Lempang Kecamatan Tanete Riaja Kabupaten Barru.

\section{Harga jual}

Menurut Ricky W. dan Ronald J. Ebert mengemukakan bahwa "penetapan harga jual adalah proses penentuan apa yang akan diterima suatu perusahaan dalam penjualan produknya. Mulyadi menyatakan bahwa "pada prinsipnya harga jual harus dapat menutupi biaya penuh ditambah dengan laba yang wajar. Harga jual sama dengan biaya produksi ditambah mark-up. Selain itu Hansen \& Mowen mengemukakan bahwa "harga jual adalah jumlah moneter yang dibebankan oleh suatu unit usaha kepada pembeli atau pelanggan atas barang atau jasa yang dijual atau diserahkan.

Hukum Target Costing yang dikemukakan oleh Blocher, dkk. Menunjukkan bahwa laba yang diinginkan merupakan harga jual yang ditentukan oleh pasar dikurang dengan biaya produksi yang dikeluarkan sehingga target earning atau laba yang diharapkan berpengaruh terhadap harga jual sebuah produk (Blocher, 2000). 
Dari defenisi di atas dapat disimpulakan bahwa harga jual adalah sejumlah biaya yang dikeluarkan perusahaan untuk memproduksi suatu barang atau jasa ditambah dengan persentase laba yang diinginkan perusahaan, karena itu untuk mencapai laba yang diinginkan oleh perusahaan salah satu cara yang dilakukan untuk menarik minat konsumen adalah dengan cara menentukan harga yang tepat untuk produk yang terjual. Harga yang tepat adalah harga yang sesuai dengan kualitas produk suatu barang, dan harga tersebut dapat memberikan kepuasan kepada konsumen.

\section{Pemasaran}

Pemasaran (marketing) bersangkut paut dengan kebutuhan hidup sehari-hari kebanyakan orang. Melalui proses tersebut suatu produk atau jasa diciptakan. Kebanyakan orang menganggap bahwa pemasaran sama dengan penjualan dan promosi, padahal tidaklah demikian. Hakikatnya, pemasaran adalah kegiatan manusia yang diarakan untuk memenuhi kebutuhan dan keinginan melalui proses pertukaran. Konsep penting dalam pemasaran adalah kebutuhan, keinginan, permintaan, produk, pertukaran, transaksi dan pasar.

Menurut WY. Stanton, pemasaran adalah sesuatu yang meliputi seluruh sistem yang berhubungan dengan tujuan untuk merencanakan dan menentukan harga sampai dengan mempromosikan dan mendistribusikan barang dan jasa yang bisa memuaskan kebutuhan pembeli aktual maupun potensial (Oentoro, 2012).

\section{Modal Usaha dan Pendapatan}

Modal merupakan input (faktor produksi) yang sangat penting dalam menentukan tinggi rendahnya pendapatan. Tetapi bukan berarti merupakan faktor satu-satunya yang dapat meningkatkan pendapatan. Sehingga dalam hal ini, modal bagi pengusaha juga merupakan salah satu faktor produksi yang mempengaruhi tingkat pendapatan.

Modal adalah semua bentuk kekayaan yang dapat digunakan langsung maupun tak langsung dalam proses produksi untuk menambah output. Terbatasnya modal dalam usaha rumah tangga dapat dilihat dari terbatasnya jumlah prasarana dan terbatasnya alat-alat modal yang modern yang dapat digunakan dalam kegiatan produksi. Hal ini merupakan salah satu faktor penting yang menyebabkan tingkat pendapatan.

\section{Harga Jual dan Pendapatan}

Harga adalah banyaknya uang yang dibayarkan oleh pelanggan untuk produk tersebut.Harga sangat penting mengingat hal tersebut menentukan keuntungan suatu usaha. Menyesuaikan harga memiliki dampak terhadap pemasaran produk, dan tentunya juga berpengaruh terhadap pendapatan yang akan diterima oleh pemilik usaha.

\section{Pemasaran dan Pendapatan}

Pemasaran merupakan salah satu kegiatan yang dilakukan oleh pengusaha, dimana kegiatan tersebut secara langsung berhubungan dengan konsumen atau calon pembeli. Sehingga dapat dikatakan bahwa keberhasilan pemasaran merupakan kunci 
kesuksesan dari suatu usaha yang akan meningkatkan pendapatan dari proses pertukaran atau transaksi.

Orientasi dari pemasaran adalah dengan melakukan promosi. Setiap perusahaan dalam melakukan kegiatan promosi didorong atau dimotivasi oleh adanya tujuan yang ditetapkan oleh perusahaan. Kegiatan promosi yang baik akan menimbulkan perhatian dan keinginan konsumen untuk menggunakan produk tertentu, sehingga permintaan akan produk tersebut akan meningkat. Disamping itu kegiatan promosi yang baik akan meningkatkan popularitas produk dan memelihara hubungan dengan konsumen.

\section{METODE PENELITIAN}

Lokasi yang menjadi tempat penelitian adalah industri kerajinan batu tatakan di Desa Lempang Kecamatan Tanete Riaja Kabupaten Barru.Waktu penelitian yang digunakan satu sampai dua bulan lamanya, dari bulan November 8 sampai bulan Desember 2018.Populasi yang ada di objek penelitian ini adalah semua masyarakat yang bermata pencaharian sebagai pengrajin batu tatakan yang tercakup dalam kriteria tersebut sebanyak 126.Penelitian ini, menggunakan penentuan sampel menggunakan rumus Slovin dan menghasilkan 96 responden.Data diperoleh melalui jawaban kuesioner yang diperoleh dari para pengrajin batu tatakan yang menjadi objek penelitian beserta hasil wawancara dengan pihak-pihak terkait. Metode analisis yang digunakan untuk menguji hipotesis adalah regresi linear berganda dengan alat analisis output eviews 9 sebagai berikut:

$$
\begin{aligned}
& \operatorname{Ln} Y= \beta_{0}+\beta_{1} \ln X_{1}+\beta_{2} \ln X_{2}+\beta_{3} \ln X_{3}+\beta_{4} \ln X_{4}+\mu \\
& \text { Dimana : } \\
& Y=\text { Pendapatan pengrajin batu tatakan }(\mathrm{Rp}) \\
& \beta 0=\text { Konstanta } \\
& \beta 1=\text { Koefisien modal } \\
& \beta 2=\text { Koefisien harga jual } \\
& \beta 3=\text { Koefisien Pemasaran } \\
& \\
& X 1=\text { Modal }(\mathrm{Rp}) \\
& \\
& \mathrm{X} 2=\text { Harga jual }(\mathrm{Rp}) \\
& \mathrm{X} 3=\text { Pemasaran } \\
& \mu=\text { Error Term }
\end{aligned}
$$

\section{PEMBAHASAN}

\section{Gambaran Umum Responden dan Industri Batu Tatakan Mutiara Gunung}

Penelitian ini dilakukan terhadap pengrajin batu tatakan di Desa Lempang Kecamatan Tanete Riaja Kabupaten Barru. Proses pengumpulan data dilakukan dengan menyebarkan kuesioner dan melakukan wawancara langsung kepada responden yaitu pengrajin batu tatakan di Desa Lempang Kecamatan Tanete Riaja Kabupaten Barru. Jumlah kuesioner yang disebarkan berdasarkan penentuan rumus slovin sebanyak 96 kuesioner. 
Usaha industri batu tatakan mutiara gunung merupakan usaha rumah tangga yang telah turun temurun dijalankan oleh masyarakat Desa Lempang.Industri ini memanfaatkan sumber daya alam berupa batu gunung yang diolah sedemikian rupa sehingga menjadi barang-barang yang memiliki nilai guna dan nilai jual. Barangbarang yang dihasilkan dari industri ini yaitu ulekan/cobekan, penyangga rumah panggung, batu nisan, cipping/kerikil, dll.

\section{Hasil Uji Determinasi}

Berdasarkan tabel di bawah ini, maka dapat dilihat bahwa nilai output koefisien determinasi dapat dilihat dari nilai R-Squared dan Adjusted R-Squared. Dengan nilai R-Squared sebesar 0,908 dengan kata lain hal ini dapat disimpulkan bahwa besar persentase variasi jumlah pendapatan pengrajin yang dapat dijelaskan oleh variasi tiga variabel bebas yaitu modal usaha (X1), harga jual (X2), dan pemasaran (X3) sebesar 90,81\% atau 0,908149, Sedangkan sisanya dengan nilai 9,19\% atau 0,919 yang dijelaskan oleh variabel-variabel yang tidak masuk dalam penelitian ini.

Tabel 1. Koefisien Determinasi $\left(\mathrm{R}^{2}\right)$

\begin{tabular}{cc}
\hline R-Squared & 0.908149 \\
\hline Adjusted R-Squared & 0.905154 \\
\hline
\end{tabular}

Sumber: Output Eviews 9, data diolah tahun 2018

\section{Hasil Uji Simultan (UJi F)}

Uji simultan ini bertujuan untuk mengetahui apakah variabel modal usaha, harga jual, dan pemasaran secara simultan berpengaruh signifikan terhadap pendapatan pengrajin batu tatakan. Hal ini dapat menunjukkan bahwa apabila nilai signifikan < 0,05 maka variabel independen secara bersama-sama memiliki pengaruh terhadap veriabel dependen, artinya perubahan yang terjadi pada variabel terikat dapat dijelaskan oleh perubahan variabel bebas di mana tingkat signifikan yang digunakan yaitu 0,05 atau 5\%. Jadi dlihat pada tabel di bawah ini dengan menggunakan output eviews 9 dengan hasil yaitu :

Tabel 2. Uji Simultan (Uji F)

\begin{tabular}{ll}
\hline F-Statistic & 303.2090 \\
\hline Prob (F-Statistic) & 0.000000 \\
\hline
\end{tabular}

Sumber : Output Evies 9, data diolah tahun 2018

Berdasarkan dari tabel 4.11, dapat dilihat bahwa pengaruh variabel modal usaha, harga jual, dan pemasaran terhadap pendapatan pengrajin batu tatakan maka diperoleh nilai Prob (F-Statistic) dengan nilai 0,000000<0,05. Seperti yang dijelaskan uji F di atas. 


\section{Analisis Regresi Linear Berganda}

Berdasarkan pengolahan data penelitian yang telah dikumpulkan melalui kuesioner, baik untuk variael terikat yakni prndapatan pengrajin (Y) maupun variabel bebas yang meliputi modal usaha (X1), harga jual (X2), dan pemasaran (X3) maka diperoleh hasil perhitungan regresi linear berganda sebagai berikut:

Tabel 3. Hasil Uji Regresi Linear Berganda

\begin{tabular}{lllll}
\hline Variable & Coefficient & Std. Error & t-Statistic & Prob. \\
\hline C & 0.141308 & 0.274359 & 0.515047 & 0.6078 \\
Modal Usaha & 0.045487 & 0.039619 & 1.148115 & 0.2539 \\
Harga Jual & -0.001343 & 0.068107 & -0.019722 & 0.9843 \\
Pemasaran & 0.912315 & 0.053528 & 17.04376 & 0.0000 \\
R-squared & 0.908149 & Mean dependent var & 6.993634 \\
Adjusted R-squared & 0.905154 & S.D. dependent var & 0.411782 \\
S.E. of regression & 0.126817 & Akaike info criterion & -1.251375 \\
Sum squared resid & 1.479587 & Schwarz criterion & -1.144527 \\
Log likelihood & 64.06598 & Hannan-Quinn criter. & -1.208185 \\
F-statistic & 303.2090 & Durbin-Watson stat & 1.864960 \\
Prob(F-statistic) & 0.000000 & & \\
\hline Sumber: Output Eviews 9, data diolah tahun 2018. &
\end{tabular}

Berdasarkan hasil regresi linear berganda pada tabel 4.14, maka diperoleh model persamaan regresi sebagai berikut:

$\operatorname{Ln} Y=\beta_{0}+\beta_{1} \ln X_{1}+\beta_{2} \ln X_{2}+\beta_{3} \ln X_{3}+\beta_{4} \ln X_{4}+\mu$

$Y=0.141308+0.045487 X_{1}-0.001343 X_{2}+0.912315 X_{3}+e$

\section{Pengaruh Modal Usaha Terhadap Pendapatan Pengrajin Industri Batu Tatakan Mutiara Gunung}

Hasil uji berdasarkan uji hipotesis, variabel modal usaha berpengaruh negatif dan tidak signifikan terhadap pendapatan pengrajin batu tatakan mutiara gunung Desa Lempang Kecamatan Tanete Riaja Kabupaten Barru.

Penelitian ini sejalan dengan penelitian yang dilakukan oleh Harisna Rais dengan judul pengruh struktur modal dan pengelolaan modal kerja terhadap profitabilitas perusahaan di daftar efek syariah perusahaan.Adapun hasilnya yaitu secara parsial struktur modal berpengaruh secara negatif namun tidak signifikan atau dapat dikatakan tidak berpengaruh terhadap tingkat profitabilitas. Hal ini dibuktikan dengan nilai $t$ statistik sebesar 0,812 dengan nila $p$ value atau signifikansi 0,418 yang lebih besar dari 0,05 $(0,418>0,050)$ dan koefisien regresi sebesar $-0,166$. Hal ini memberikan indikasi bahwa setiap kenaikan ataupun penurunan struktur modal perusahaan tidak akan berpengaruh pada kenaikan ataupun penurunan tingkat profitabilitas perusahaan. 
Hasil ini tidak sejalan dengan penelitian yang dilakukan oleh Ahmad Ridha dan Suraiya Putri dengan judul faktor-faktor yang mempengaruhi pendapatan usaha kerajinan tas aceh di Desa Madon Kecamatan Muara Batu Kabupaten Aceh Utara dengan hasil regresi yaitu koefisien regresi sebesar 2,101 yang menunjukkan bahwa jika modal usaha meningkat sebesar satu satuan maka akan meningkatkan pendapatan kerajinan tas Aceh sebesar 2,101 satuan dan nilai $t_{\text {hitung }}>t_{\text {tabel }}(2,850>$ 2178), dengan nilai signifikansi 0,012 lebih kecil dari 0,05 sehingga variabel modal usaha berpegaruh positif dan signifikan terhadap pendapatan pengrajin tas Aceh di Desa Ulee Madon (Putri, 2017).

\section{Pengaruh Harga Jual Terhadap Pendapatan Pengrajin Industri Batu Tatakan Mutiara Gunung}

Hasil uji berdasarkan uji hipotesis, variabel harga jual berpengaruh negatif dan tidak signifikan terhadap pendapatan pengrajin batu tatakan mutiara gunung Desa Lempang Kecamatan Tanete Riaja Kabupaten Barru.

Seperti halnya penelitian yang dilakukan oleh Ekatherina O.K dengan judul analisis pengaruh harga jual produk terhadap profitabilitas perusahaan pada PT. Mega Eltra (persero) cabang Medan.Hasil pengujian ini menunjukkan bahwa harga jual semen tidak mempunyai pengaruh yang signifikan terhadap tingkat profitabilitas perusahaan. Hasil ini dapat dilihat pada pengujian t-test yang menunjukkan angka signifikansi (sig) harga jual berada di atas 0,05 yaitu 0,138 dengan tingkat kepercayaan 95\% (Ekatherina, 2008).

Sedangkan penelitian yang dilakukan oleh Josephine Wuri dan Yuliana Rini Hardanti tidak sejalan dengan penelitian ini. Adapun judul penelitiannya yaitu peranan industri kecil dalam meningkatkan pendapatan masyarakat kasus pada industri kerajinan batik kau di Dusun Krebet, Sendangsari, Pajangan, Bantul dengan hasil nilai thitung untuk variabel nilai produksi atau harga jual adalah sebesar 8,299 dan $t_{\text {tabel }}$ adalah 2,048 maka $\mathrm{H}_{0}$ ditolak. Hal ini menunjukkan bahwa variabel nilai produksi berpengaruh secara positif dan signifikan terhadap tingkat keuntungan pengrajin, artinya apabila nilai produksi naik sebesar satu persen maka tingkat keuntungan pengrajin akan meningkat sebesar 0,95 persen, ceteris paribus (Hardanti, 2006).

\section{Pengaruh Pemasaran Terhadap Pendapatan Pengrajin Industri Batu Tatakan Mutiara Gunung.}

Hasil uji berdasarkan uji hipotesis, variabel pemasaran berpengaruh positif dan signifikan terhadap pendapatan pengrajin batu tatakan mutiara gunung Desa Lempang Kecamatan Tanete Riaja Kabupaten Barru.

Seperti halnya yang diteliti oleh Kartika Pangayoman dan Luthfi Muta'ali dengan judul faktor-faktor yang mempengaruhi pendapatan industri kerajinan marmer di Kecamatan Campurdarat Kabupaten Tulungagung, yang mengemukakan bahwa terdapat hubungan yang signifikan antara pemasaran dengan pendapatan industri, hal tersebut ditunjukkan dengan nilai signifikan sebesar 0,021 dan nilai koefisien sebesar 0,627 yang menggambarkan bahwa adanya hubungan yang kuat, patut diduga variabel pemasaran berpengaruh terhadap pendapatan industri, di 
mana pemasaran dapat mendongkrak penjualan yang kemudian akan berdampak pada pendapatan industri kerajinan marmer.

Sedangkan penelitian yang dilakukan oleh Eka Putri Hidayati dan Yoyok Soesatyo dengan judul yaitu pengaruh modal kerja dan strategi pemasaran terhadap keberhasilan usaha kerajinan manik-manik kaca Desa Plumbon Gambang Kcamatan Gudo Kabupaten Jombang tidak sejalan dengan hasil penelitian ini, Adapun hasilnya yaitu mengemukakan bahwa nilai $\mathrm{t}$ hitung variabel strategi pemasaran adalah sebesar -0,135 dengan tingkat signifikansi sebesar 0,893>0,05 atau 5\%, artinya variabel strategi pemasaran mempunyai pengaruh yang tidak signifikan tehadap variabel keberhasilan usaha pada sentra industri kecil kerajinan manik-manik kaca Desa Plumbon Gambang Kecamatan Gudo Kabupaten Jombang.

\section{PENUTUP}

Berdasarkan dari hasil analisis dan data yang dikemukakan oleh peneliti yang berjudul Faktor-Faktor Yang Mempengaruhi Pendapatan Pengrajin Industri Batu Tatakan Mutiara Gunung Desa Lempang Kecamatan Tanete Riaja Kabupaten Barru dapat ditarik kesimpulan bahwa :Variabel Modal Usaha berpengaruh positif dan tidak signifikan terhadap pendapatan pengrajin batu tatakan mutiara gunung Desa Lempang, hal ini dikarenakan modal usaha yang digunakan oleh setiap pengrajin berbeda-beda sesuai dengan kepemilikan barang modal setiap pengrajin. Variabel Harga Jual berpengaruh negatif dan tidak signifikan terhadap pendapatan pengrajin batu tatakan mutiara gunung Desa Lempang,hal ini dikarenakan apabila terjadi peningkatan harga jual dari produk kerajinan maka menyebabkan kurangnya permintaan oleh konsumen, sehingga tidak terjadi keseimbangan pasar atau ekuilibrium yang menyebabkan turunnya pendapatan pengrajin industri batu tatakan. Variabel Pemasaran berpengaruh positif dan signifikan terhadap pendapatan pengrajin batu tatakan mutiara gunung Desa Lempang, hal ini dikarenakan semakin banyak jumlah produk yang dihasilkan maka semakin banyak pulalah peluang pendapatan yang akan diterima oleh pengrajin/produsen. Dari hasil Uji t statisik menunjukkan bahwa diantara ke tiga variabel bebas hanya satu variabel yang berpengaruh secara signifikan terhadap variabel terikat, yaitu variabel pemasaran industri batu tatakan.

\section{DAFTAR PUSTAKA}

Ahmad Ridha dan Suraiya Putri, Faktor-Faktor Yang Mempengaruhi Pendapatan Usaha Kerajinan Tas Aceh di Desa Ulee Madon Kecamatan Muara Batu Kabupaten Aceh Utara, Jurnal Samudra Ekonomika, Vol 1, No.1 (2017)

Blocher, dkk. Manajemen Biaya, diterjemahkan oleh Susty A. Ambarsiani Jakarta: Salemba Empat. (2000)

Dumairy, Prinsip-prinsip Ekonomi. Jakarta: Erlangga. (2006)

Eka Putri Hidayati dan Yoyok Soesatyo, Pengaruh Modal Kerja dan Strategi Pemasaran Terhadap Keberhasilan Usaha Kerajinan Manik-Manik Kaca Desa Plumbon Kecamatan Gudo Kabupaten Jombang. Jurnal Ekonomi, Universitas Negeri Surabaya. 
Ekatherina O.K. Analisis Pengaruh Harga Jual Produk Terhadap Profitabilitas Perusahaan Pada PT. Mega Eltra (Persero) Cabang Medan. Skripsi. Fakultas Ekonomi Universitas Sumatra Utara. (2008)

Hendro, Dasar-Dasar Keirausahaan : Panduan Bagi Mahasiswa Mengenal, Memahami dan Memasuki Dunia Bisnis Jakarta: Erlangga. (2011)

Kartika Pangayoman dan Luthfi Muta'ali, Faktor-Faktor Yang Mempengaruhi Pendapatan Industri Kerajinan Marmer Di Kecamatan Campurdarat Kabupaten Tulungagung. Jurnal Manajemen dan Bisnis, Vol.16, No.2,

Muhammad Sharif Chaudry, Sistem Ekonomi Islam. Jakarta: Kencana Prenada Media Grup, (2012).

Ni Luh Sili Antari, Pengaruh Pendapatan, Pendidikan, dan Remitan Terhadap Pengeluaran Konsumsi Pekerja Migran Nonpermanen Di Kabupaten Bandung (Studi Kasus Pada Dua Kacamatan Di Kabupaten Bandung). Jurnal Ekonomi (Jurusan Ekonomi Pembangunan Universitas Udayana. (2008)

Oentoro, Deliyanti SE.,MM. Manajemen Pemasaran Modern. Yogyakarta: LaksBang PRESSindo. (2012)

Pratama Rahardja dan Mandala Manurung, Teori Ekonomi Mikro Suatu Pengantar (Jakarta: Lembaga penerbit Fakultas Ekonomi Universitas Indonesia. (2016)

Soesarsono Wijandi, Pengantar Kewirausahaan, Cet.IV (Bandung: Sinar Baru Algesindo, (2004)

Sukirno, Sadono Mikroekonomi Teori Pengantar Edisi Ketiga. Jakarta: Raja Grafindo Persada. (2006)

--------. Pengantar Teori Ekonomi Mikro. Jakarta: PT. Raja Grafindo Persada. (1999)

Yuliana RiniHardantidan Josephine Wuri, Peranan Industri Kecil Dalam Meningkatkan Pendapatan Masyarakat Kasus Pada Industri Kerajinan Batik Kayu Di Dusun Krebet, Sendangsari, Pajangan, Bantul. Jurnal Kinerja, Vol. 10, No. 2, Yogyakarta: Universitas Sanata Dharma Yogyakarta. (2006) 